\title{
SIMULATION OF THE ORBITING SPACECRAFT TO ANALYSIS AND UNDERSTAND THEIR ROTATION BASED ON PHOTOMETRY
}

\author{
Koshkin N. ${ }^{1}$, Melikyants S. ${ }^{1}$, Korobeinikova E. ${ }^{1}$, Shakun L. ${ }^{1}$, Strakhova S. ${ }^{1}$, \\ Kashuba V. ${ }^{1}$, Romanyuk Ya. ${ }^{2}$, Terpan S. ${ }^{1}$ \\ ${ }^{1}$ Astronomical Observatory, Odessa National University, Odessa, Ukraine, \\ nikkoshkin@yahoo.com \\ ${ }^{2}$ MAO NASU, Kyiv, Ukraine
}

\begin{abstract}
Analysis of the photometric information allows to determine the parameters of spacecraft rotation. We will consider the light curves of a rotating satellite. Smooth changes in brightness, which are caused by diffuse scattering of sunlight, are characterized by the amplitude, quantity, shape and asymmetry of brightness variation during the rotation period of the body. In addition, the so-called "specular" flashes of light of very large amplitude are present on light curves. By analyzing the observed light curves of the inactive satellites Topex/Poseidon and Sich-2, the determination of pole orientation these objects in space is demonstrated. To interpret the light curve's contained information, we are planning to creat optical-geometrical models of this satellite and simulated geometrical conditions by its orbit passages. Further comparison of the model and observed light curves should allow us to confirm the correctness of the satellite attitude determination. For the simulation, we used the MaxScript programming language, which allows to create a satellite model, and simulate the opticalgeometric conditions of its passage, including the complex rotation of the spacecraft.
\end{abstract}

Keywords: Earth's artificial satellite, space object, photometry, light curve, rotation period.

АНОТАЦІЯ. Для контролю навколоземного космічного простору використовуються оптичні засоби спостереження. Аналіз фотометричної інформації дозволяє визначити параметри обертання космічного апарату. Ми розглянули криві блиску супутника, що обертається. Плавні зміни блиску, які обумовлені дифузним розсіюванням сонячного світла, характеризуються амплітудою, кількістю, формою і асиметрією коливань блиску протягом періоду обертання тіла. Крім того, на реєстрованих кривих блиску присутні так звані "дзеркальні" спалахи блиску, тобто короткочасні підвищення блиску дуже великої амплітуди. Такі спалахи блиску обумовлені дзеркальним відбиттям сонячного світла від гладких поверхонь на корпусі КО. На основі аналізу спостережуваних кривих блиску неактивних супутників Topex/Poseidon та Sich-2 викладено методику визначення орієнтації цих об'єктів у просторі. Щоб інтерпретувати інформацію, що міститься в кривій блиску, ми плануємо створити детальні оптико-геометричні моделі цього супутника і симулювати геометричні умови в його проходах по орбіті. Подальше порівняння моделі i спостережуваних кривих блиску має дозволити нам підтвердити правильність визначення орієнтації супутника. Для моделювання ми використовували мову програмування MaxScript, який дозволяє створювати модель супутника і моделювати оптикогеометричні умови його проходження, в тому числі складне обертання космічного корабля.

Ключові слова: Штучний супутник Землі, космічний об'єкт, фотометрія, крива блиску, період обертання.

Optical surveillance tools are used to of near-Earth space situations awareness. A satellite moving in orbit around the Earth is visible to the observer when it is illuminated by the Sun. Registration of the satellite's position against the background of stars allows us to solve the problem of the subsequent determination of its orbital parameters. In the case of inactive $\mathrm{SO}$, the problem of determining its own rotation around the center of mass is solved by two types of measurements - high-frequency laser ranging (in the case when the target object is equipped with corner cube reflectors, CCR) and high-quality high-speed photometry (in all other cases) (Kucharski D. et al., 2018; Schildknecht Th. et al., 2015). The motion of the satellite relative to the center of mass is of great importance for many applications - from actively removing an inactive satellite (space debris) from orbit to accurately determine the real orbit to conjunction predict with other resident space objects.

If telescope track the space object along visible flight trajectory above the surveillance point, then it is possible to register a change in its brightness over a long time interval. This process is called photometry and the result is the socalled "light curve" of SO. Obviously, the density of the radiation flux reflected by the SO surface in direction of the observer (photometer) depends on the body shape and the optical characteristics of its surface, and its variation is determined by the changing geometric conditions of lighting and the aspect of the SO visibility, as well as its own rotation around the center of mass. In many cases, we do not have information about the real optical characteristics of the SO surface (indicatrixes of light scattering of different parts of the body) and even a specific configuration of the SO body shape not always is known (for example, location of solar panel relative to the body, or the composition of all parts of the SO after fragmentation). 


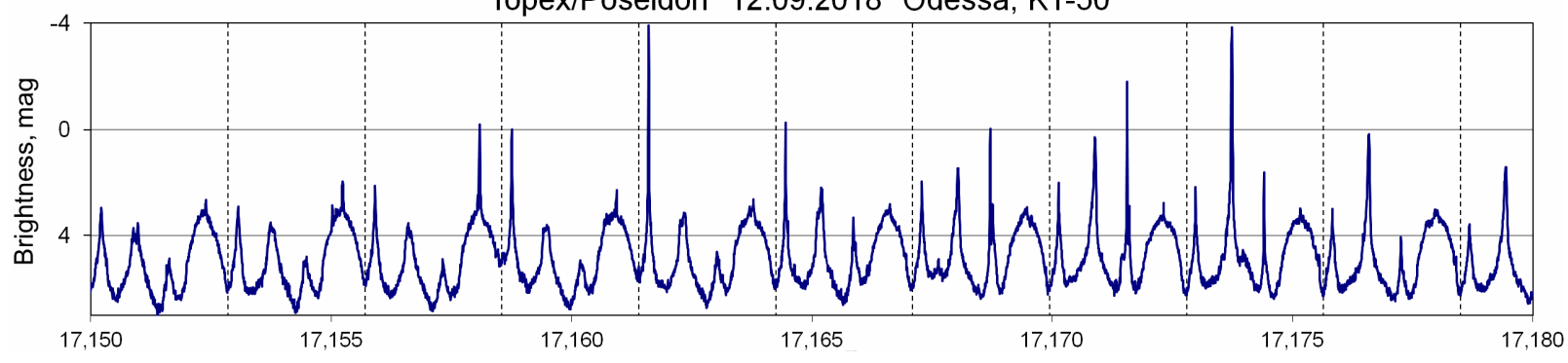

Figure 1: A fragment of the light curve of the rotating Topex satellite obtained September 12, 2018 using KT-50 telescope in Odessa

Consider the light curves of a rotating SO. Smooth changes of the brightness, which are caused by diffuse scattering of sunlight, are characterized by the amplitude, quantity, shape and asymmetry of the maximums and minimums of brightness during the rotation period of the body. In addition, so-called "specular" flashes of the brightness are often present on recorded light curves, that is, short-term increases in brightness, often of very large amplitude (from 1 to 5-6 magnitudes). Such flashes of brightness are caused by specular reflection of sunlight by smooth surfaces on the SO body. It can be flat surfaces or so-called "developable surfaces" (for example, cylindrical or conical), which are a smooth surface with zero Gaussian curvature. When the normal to a flat surface or to one of the developing surfaces coincides with the phase angle bisector (PAB), then there is a specular reflection of sunlight in the direction of the observer.

Since the diffuse component in the light curve is rather difficult to analyze, if there is no exact information on the indicatrixes and reflection coefficients of the SO surface elements, then we can focus on the analysis of specular flashes. If the direction of "SO-observer" did not change in space, the interval between successive short-term flashes of brightness would accurately characterize the rotation period of the satellite in the fixed (inertial) coordinate system. In fact, this is not so, and the interval between flashes is called the "visible" (or synodic) period of the SO rotation. The visible period is determined by the vector sum of two rotations - the SO's own rotation and its orbital motion relative to the observer. In this paper, we consider some of the observed features of the alternation of specular flashes and changes in the visible rotation period using the example of the light curves of the inoperative Topex/Posseidon satellite (Koshkin N. et al., 2017; Atlas of light curves of space objects, 2014-2015; Atlas of light curves of space objects, 2016-2018).

Figure 1 shows a fragment of the representative light curve of a freely rotating former Topex satellite. This light curve was obtained on September 12, 2018 using the KT-50 telescope in Odessa. A characteristic feature is the presence of periodic bright flashes of light. Sharp specular maxima, characterized by rapid increase and decrease in brightness, are especially noticeable. The apparent period of the satellite rotation is marked by vertical dashed lines on the graph. In this fragment of the light curve during one revolution of the satellite, we see one broad "diffuse" maximum, with which a specular flash also sometimes coincides, and three sharp maxima are approximately equally spaced. The amplitudes of all specular brightness

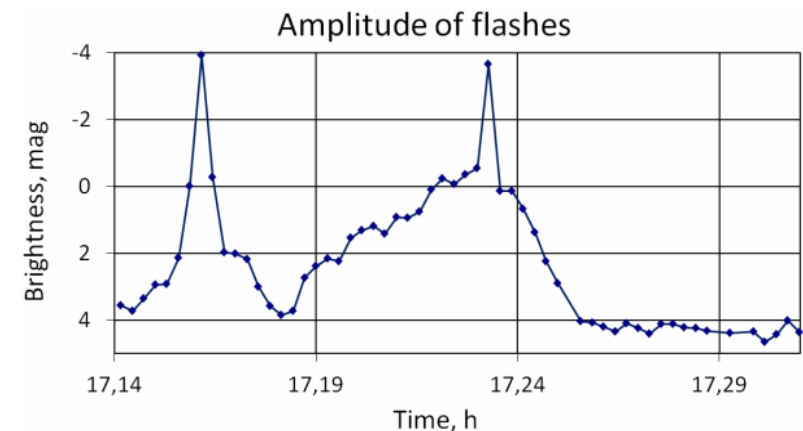

Figure 2: The change of amplitude of specular flashes during the satellite passage above the observation point in Odessa.

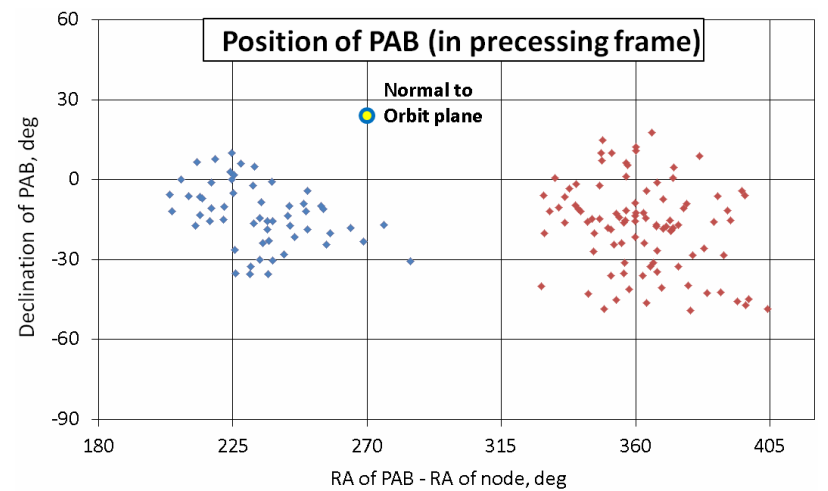

Figure 3: The position of the $\mathrm{PAB}$ vectors for 152 light curves of Topex obtained from September 1, 2009 to October 18, 2018.

fluctuations are not constant. Four maximums per period may indicate that the light-reflecting planes are located on the sides of the satellite body, which has the shape of a rectangular prism (a box).

Let us first consider one sequence of specular flashes of brightness following after a broad maximum in each cycle. This outburst is observed with different intensities throughout the curve. Figure 2 shows the change in its amplitude during the passage of the satellite above the observation point. We see that its amplitude experienced both slow and fast changes and rapidly increase twice, when specular reflection of light was occur, and the reduced to the standard distance brightness reached $-4 \mathrm{~m}$ at this time. This should indicate a variation in the angular distance between the normal to the light-reflecting surface and the phase angle bisector. The trajectory of the PAB is an arc in the celestial sphere, and it can be assumed that during the 
satellite passage the same normal to a flat smooth face move closer on a certain small angle in relation the PAB twice, when the observer could see a specular reflection at the corresponding phase of the body rotation.

For all 152 light curves of Topex obtained by us from September 1, 2009 to October 18, 2018, we calculated the positions of the $\mathrm{PAB}$ vector at the moments when the flashes has specular character and amplitude of the light fluctuations are noticeable increase. Figure 3 shows the all positions of the $\mathrm{PAB}$ in a slowly rotating coordinate system, which the $\mathrm{Z}$ axis coincides with rotation pole of the Earth, and the $X$ axis lies at the equator plane and is directed to ascending node of the Topex orbit.

We see that the positions of the PABs at the moments of bright specular flashes are concentrated in a limited region. This indicates that the rotation pole is "fixed" (and are fixed with it the orientation of Topex body itself) in the orbital coordinate system for a very long monitoring time. However, the separation of the positions of $\mathrm{PAB}$ vectors into two separate limited regions was unexpected. This should indicate that the considered sequence of specular flashes is produced by surfaces with different direction of the normal. The scattering of points in each region can also be caused by nutation oscillations of the satellite rotation axis.

Let the moments of successive flashes of brightness of any one face of a satellite rotating with a certain constant period be calculated for a stationary observer as

$$
\mathrm{T}_{\mathrm{N}, \text { calc }}=\mathrm{T}_{0}+\mathrm{P}_{\text {Inert }} * \mathrm{~N} \text {, }
$$

where $\mathrm{T}_{0}$ is the first moment of the sequence, $\mathrm{P}_{\text {Inert }}$ is the inertial period of rotation, $\mathrm{N}$ is the cycle number. The real moments of observed flashes twill be shifted relative to such the linear ephemeris due to a change of the phase angle and aspect of observation caused by orbital motion. In fig. 4 filled dots show the phase shift of the considered repeated outbursts relative to the linear ephemeris with inertial period of 10.2665941 seconds. We see that, despite a twofold increase in the amplitude, the phase shift of this flashes occurs smoothly and does not imply two different reflecting surfaces on the satellite's body.

Moreover, it is possible to find the position of the assumed rotation axis of the satellite at which the longitude displacement of the $\mathrm{PAB}$ vector is of the same range. In fig. 4 the dashed line shows the shift of the longitude (phase) of the PAB vector in this Topex' passage dated 09/12/2018 for the rotation axis with coordinates: right ascension $\alpha_{\Omega}=100^{\circ}$ and declination $\delta_{\Omega}=26^{\circ}$. However, this solution for the Topex' rotation pole is significantly different from the value that follows from the pole motion model found in Kucharski (Kucharski et al., 2017). If light reflection, at the moments of these flashes of brightness, was produced by a flat face, then the phase shift of the flashes would be well described by just such model, and the found position of the rotation axis in this passage would correspond to the real one. However, in the case of Topex, we are apparently dealing with a different phenomenon.

Firstly, the Topex' light flashes that follow after a broad maximum on the light curves are observed in many passes almost throughout the entire observation time with variable light intensity and degree of specularity. Secondly, as mentioned above, the phase displacement of flashes produced different planar faces should be similar and described by the model of PAB phase displacement. Figure 5 shows the phase shift of two series of flashes - the flash

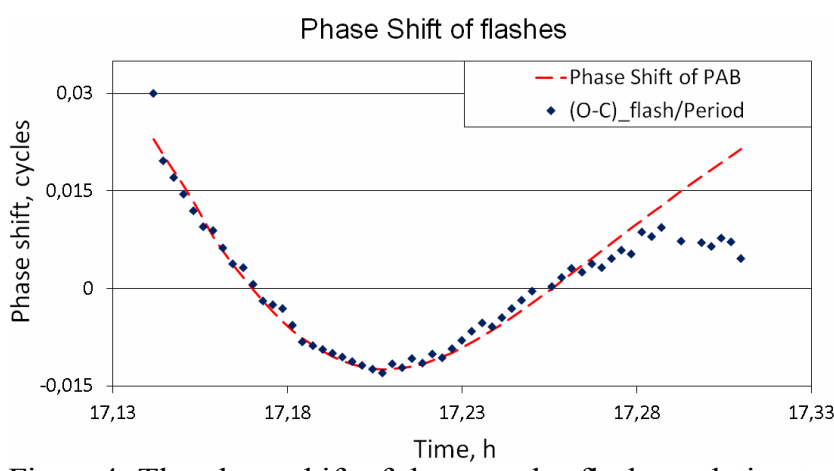

Figure 4: The phase shift of the specular flashes relative to the linear ephemeris with inertial period of 10.2665941 seconds (dots). Dashed line shows the shift of the longitude of the PAB vector in this Topex passage dated $09 / 12 / 2018$ for the rotation axis with coordinates: right ascension $\alpha_{\Omega}=100^{\circ}$ and declination $\delta_{\Omega}=26^{\circ}$.

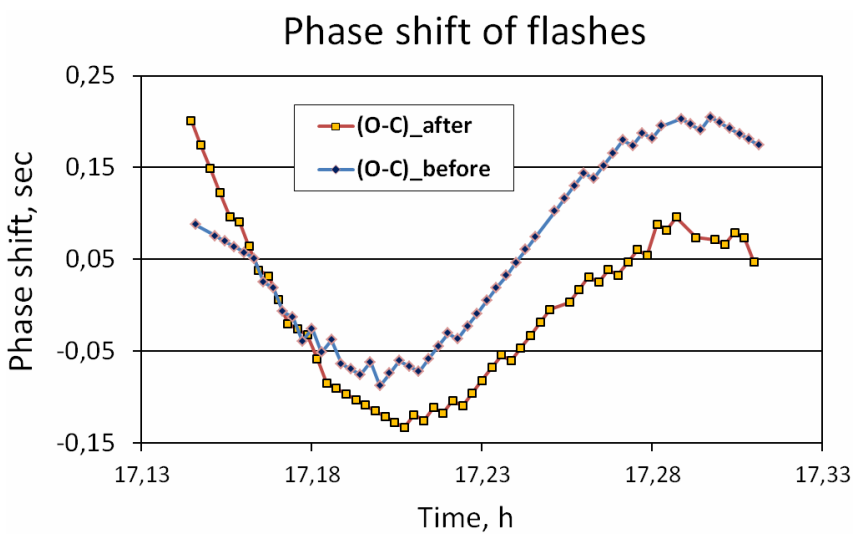

Figure 5: The phase shift of two series of flashes - the flash series after a wide maximum (as in fig. 4), and another flash series appearing before wide maximum.

series after a wide maximum (discussed above), and another flash series appearing before this maximum. We note the non-synchronous phase shift of these two different flashes. The phase difference between them reaches $0.1 \mathrm{sec}$ or $1 \%$ of the rotation period. This may mean that at least one of the flashes is due to reflection from a non-planar surface.

We calculated the positions of the $\mathrm{PAB}$ vectors for another inactive satellite Sich-2 at those moments when the specular character of flashes is observed with a noticeable increase in the amplitude of the brightness oscillations. This space object is a rectangular prism with four solar panels and its light curves also occasionally present of the specular light reflection by the body surface (Koshkin et al., 2018). Figure 6 shows all the positions of the PAB in a slowly rotating coordinate system (the $\mathrm{Z}$ axis of which coincides with the Earth's rotation pole, and the $\mathrm{X}$ axis lies at the equator plane and is directed to the ascending node of the Sich-2 orbit) for those passes when specular flashes of light appeared. The moments of the appearance of specular flashes of light are marked on each PAB trajectory with a red dot. We see that for the case when sunlight is reflected from flat faces, all the PAB vectors lie near one straight line on the celestial sphere. In the case of Sich-2, when the body shape is well known, it can be argued that the rotation axis of the satellite is the pole of this large circle on the sphere, and has the coordinates: right ascension $\alpha_{\Omega}=91.5^{\circ}+\alpha_{\text {node }}$ and declination $\delta_{\Omega}=+34.7^{\circ}$. 


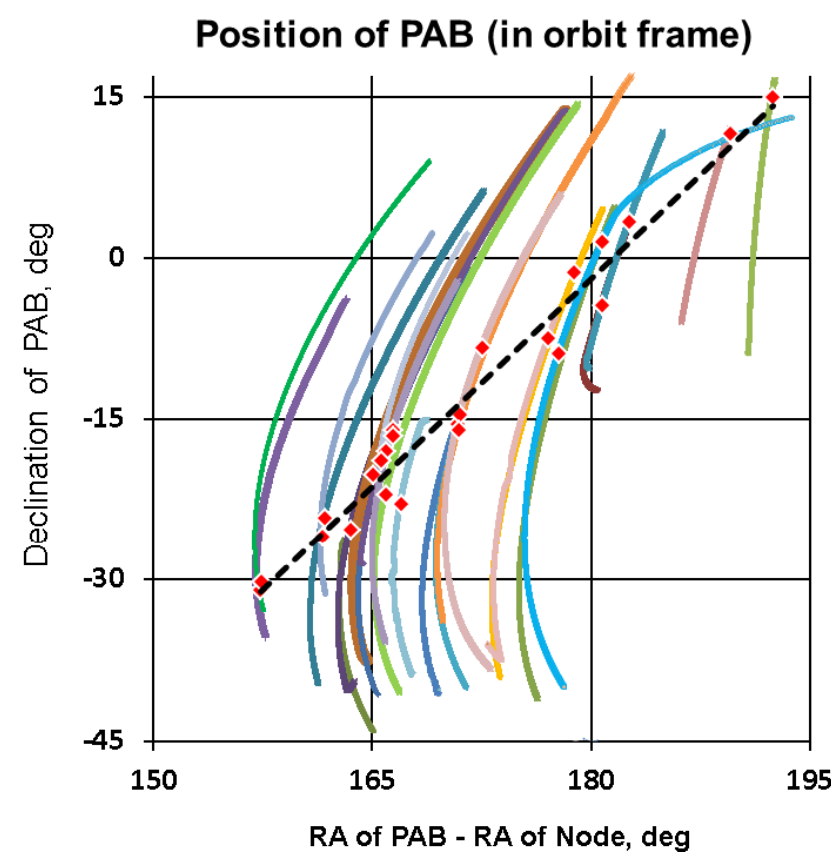

Figure 6: The positions of the $\mathrm{PAB}$ in a slowly rotating coordinate system (the $\mathrm{Z}$ axis of which coincides with the Earth's rotation pole, and the $\mathrm{X}$ axis lies at the equator plane and is directed to the ascending node of the Sich-2 orbit) for the passes when specular flashes appeared (red dots).

Summarizing the above analysis of the light curves of the inactive Topex satellite, it can be stated that the observed features of its brightness variations require consideration of the detailed shape of the body surface and the optical properties of even small structural elements. It can be assumed that long sequences of flashes (episodically very bright and specular) are due to reflection from a conical smooth surface, different parts of one have different normals direction. The separation of the $\mathrm{PAB}$ position areas in the orbital coordinate system during such bright specular flashes is expressed this. Topex computer simulation should confirm this assumption (Melikyants et al., 2007).

\section{References}

Atlas of light curves of space objects. Part 4: (2014-2015) /ed. N.I.Koshkin; Odessa, 2016, 183 p. (http://dspace. onu.edu.ua:8080/handle/123456789/8480).

Atlas of light curves of space objects Part 5: (2016-2018) / ed. N.I.Koshkin; Odessa, 2018, 295 p. (http://dspace. onu.edu.ua:8080/handle/123456789/23814).

Koshkin N., Savanevich V. et al.: 2017, Odessa Astron. Publ., 30, 226 (DOI: http://dx.doi.org/10.18524/18104215.2017.30.117655).

Koshkin N., Shakun L. et al.: 2018, Odessa Astron. Publ., 31, 179 (http://oap.onu.edu.ua/article/view/147807)

Melikyants, S., Shakun, L. et al.: 2007, Odessa Astron. Publ., 20, p. 72, (2007OAP...20...72M).

Kucharski D. et al.: 2017, AGU Earth and Space Science, 4, 661 (https://doi.org/10.1002/2017EA000329).

Kucharski D. et al.: 2018, in: Proc. 21st IWLR2018, Canberra, Australia, 5-9 Nov. 2018, https://cddis.nasa. gov/lw21/docs/2018/papers/SessionSD4_Kucharski pa per.pdf.

Schildknecht Th. et al.: 2015, in: Proc. of the Adv. Maui Optical and Space Surveillance Technologies Conf., held in Wailea, Maui, Hawaii, September 15-18, id.25 (2015amos.confE.25S), http://www.amostech.com/ TechnicalPapers/2015/NROC/Schildknecht.pdf. 